\title{
Effects of Nitrogen Treatments on Macro and Microelement Contents of Oil Sunflower (Helianthus annuus L.) Seeds
}

\author{
Volkan GUL ${ }^{1}$, Erdogan OZTURK ${ }^{1 *}$, Taskın POLAT ${ }^{1}$, Furkan COBAN $^{1}$ \\ ${ }^{1}$ Ataturk University Field Crop Departments 25240 Erzurum/TURKEY \\ erozturk@atauni.edu.tr
}

\begin{abstract}
The present study was carried out to investigate the effects of different nitrogenous fertilizer treatments through soil $\left(0,30,60,90,120\right.$ and $\left.150 \mathrm{~kg} \mathrm{~N} \mathrm{ha}{ }^{-1}\right)$ on macro and micro nutrient ( $N, P, K, C a, M g$, $\mathrm{Fe}, \mathrm{Zn}, \mathrm{Mn}, \mathrm{Cu}$ and $\mathrm{B}$ ) contents of the seeds of different oil sunflower cultivars (Isera (early), C-70165 (medium-early) and Teknosol (late)). Experiments were conducted under ecological conditions of Erzurum Province during the years 2011 and 2012 in randomized blocks experimental design with three replications. As a result, gradually increasing nitrogenous fertilizing to the soil while sowing increases $N$ and $K$ content of seeds decreases $\mathrm{P}, \mathrm{Ca}, \mathrm{Mg}, \mathrm{Fe}$ and $\mathrm{Mn}$ content of the seeds. Despite the fact that there is no specific stability, Zn content is also affected by different nitrogen doses. It were found to be significant that the effect of sunflower varieties nutrient content excluding manganese and nitrogen elements.
\end{abstract}

Keywords: Sunflower; Nitrogen; Fertilizer; Macro and Micro elements.

\section{INTRODUCTION}

Oils are essential food stuffs and play significant roles in human nutrition. They are among basic nutrients required to sustain vital activities. Vegetable oils correspond to $80-85 \%$ of world oil production and $80 \%$ of Turkish oil production (Demirci and Alparslan, 1991). Sunflower, cotton (cotton seed), peanut, sesame, soybean, flax, hemp, rape and safflower are commonly cultured for vegetable oil production. Among those plants, sunflower with high seed oil contents (22-50\%) is a significant oil crop. Sunflower oil also has high polyunsaturated fatty acid content (69\%) and low saturated fatty acid content (10\%), thus it is a highly nutritious vegetable oil (Miller et al., 1987). Since agricultural goods are the essential needs of human life, entire countries of the world adopt agricultural policies so as to meet their own needs first. However, while world population is ever increasing, the size of available agricultural lands and consequently the productions are rapidly decreasing. Thus, the main target in agricultural activities is now to get the highest yields per unit area. Beside plant genetics, several environmental factors, biotic and abiotic stress conditions have significant impacts on plant growth, development and yield levels (Kaleem et al., 2010). Fertilization is an abiotic condition with significant effects on yield and yield parameters of the plants. Amount of fertilizer to be applied should be so selected as to provide the best growth and development by taking the sufficient or insufficient plant nutrients into consideration (Gecit et al., 2009). Excessive or insufficient fertilizer applications both result in yield losses. Beside yield losses, excessive nitrogen treatments may also result in various environmental problems over agricultural fields (Grant, 2006).

Among the inputs to be provided to improve plant yields, fertilizers constitute about $58 \%$ of such inputs (Taylor et al., 2005). Nitrogen is the mostly observed insufficiency in plant production, but it is an essential and yield-improving plant nutrient. Most of the nitrogen up taken from the soil by sunflower is used until flowering and head formation period (Konya, 2008). Despite the existence of several elements in nature, plant dry matter contains $4 \%$ essential nutrients of nitrogen, phosphorus, potassium, sulphur, calcium, magnesium, iron, zinc, manganese, nickel, chlorine and molibden (Brady and Weil, 2008).

Fertilization significantly influences plant nutrient contents. While essential macro nutrients (nitrogen, phosphorus and potassium) may improve micro nutrient contents of sunflower during the vegetative period, they may decrease micro nutrient contents at head formation and later periods (Lasztity, 1983). Burt et al. (1998) indicated the significance of the amount of fertilizers to be applied and nitrogen forms in plant nutrient uptake, growth and development. 
Kastori et al. (2010) reported $\mathrm{Zn}, \mathrm{Mn}$ and Fe concentrations of hybrid sunflower cultivars respectively as between 8.28-27.55, 127.55-162.30 and 284.6-706.2 $\mathrm{mg} \mathrm{kg}^{-1}$. Pajević et al. (2004) investigated the nutrient contents of sunflower seeds and reported the highest nitrogen concentration as 5310, phosphorus as 473 , potassium as 6011, calcium as 108, magnesium as 258, iron as 572 and manganese as $136 \mathrm{~g}-100 \mathrm{~g}^{-1}$. In similar studies, Solhi and Molahoseini (2013) reported nitrogen, phosphorus, potassium, iron, manganese and zinc contents of sunflower seeds respectively as $6.05 \%$, $1.27 \%, 1.39 \%, 86.45$ and $97.27 \mathrm{mg} \mathrm{kg}^{-1}$; El-Kader et al. (2006) reported nitrogen, phosphorus, potassium, iron, zinc and manganese values respectively as between $5.55-6.00 \%, 0.90-0.97 \%, 6.12-$ $6.74 \%, 680-738,143-156$ and 156-166 mg kg${ }^{-1}$ Singhal and Mudgal (1984) reported the phosphorus content of sun flower seeds as $0.67 \%$, potassium content as $1.09 \%$, magnesium content as $1.24 \%$,zinc concentration as $44 \mathrm{mg} \mathrm{kg}^{-1}$, iron concentration as $437 \mathrm{mg} \mathrm{kg}^{-1}$ and manganese concentration as $15 \mathrm{mg}$ $\mathrm{kg}^{-1}$

Determination of the effect of nitrogenous fertilizing on nutrients in sunflower seed grain is important in terms of the yield and the quality. The aim of this study was to investigate the effects of different nitrogenous fertilizer treatments through soil on macro and micronutrients of the seeds of different oil sunflower cultivars.

\section{MATERIAL AND MeTHODS}

\subsection{Experimental Conditions}

Field experiments carried out at Agricultural Experiment and Research Centre, Faculty of Agriculture, Ataturk University in Erzurum $\left(29^{\circ} 55^{\prime} \mathrm{N}\right.$ and $41^{\circ} 16^{\prime} \mathrm{E}$; $1850 \mathrm{~m}$ above sea level) during the seasons 2011 and 2012.

Soil characteristics of the experimental fields were determined by taking soil samples form $0-20 \mathrm{~cm}$ soil layer and analyzing them with regard to relevant parameters. Experimental soils were slightly alkaline ( $\mathrm{pH} 7.73$ and 7.54) with clay-loam texture, low lime contents $(0.68 \%$ and $0.20 \%)$, moderate organic matter contents (2.23\% and 2.63\%), sufficient available phosphorus (110.9 and $130.9 \mathrm{~kg} \mathrm{ha}^{-1}$ ) and potassium (1548 and $1098 \mathrm{~kg} \mathrm{ha}^{-1}$ ) levels (Kacar, 2009). Soil samples were also subjected to 0.05 M DTPA+0.1 M TEA+ 0.01 M CaCl2 solution and Atomic Absorption Spectrophotometry analyses revealed highly low extracted low Fe (1.19-1.25 mg kg $\left.{ }^{-1}\right)$, Mn (9.03-6.03 $\left.\mathrm{mg} \mathrm{kg}^{-1}\right)$ and $\mathrm{Zn}(0.51-0.30$ $\mathrm{mg} \mathrm{kg}^{-1}$ ) contents.

Precipitation, temperature and relative humidity values observed through the plant growth periods of the years 2011 and 2012 are provided in Table 1.

Table 1. Climate data for growing seasons

\begin{tabular}{lrrrrrr}
\hline \multirow{2}{*}{ Months } & \multicolumn{2}{c}{$\begin{array}{c}\text { Precipitation } \\
(\mathbf{m m})\end{array}$} & $\begin{array}{c}\text { Temperature } \\
\left({ }^{\mathbf{0}} \mathbf{C}\right)\end{array}$ & \multicolumn{2}{c}{$\begin{array}{c}\text { Relative humidity } \\
(\boldsymbol{\%})\end{array}$} \\
\cline { 2 - 7 } & $\mathbf{2 0 1 1}$ & $\mathbf{2 0 1 2}$ & $\mathbf{2 0 1 1}$ & $\mathbf{2 0 1 2}$ & $\mathbf{2 0 1 1}$ & $\mathbf{2 0 1 2}$ \\
\hline May & 105.2 & 73.0 & 9.6 & 11.4 & 69.5 & 68.0 \\
June & 55.3 & 7.0 & 14.6 & 15.7 & 63.4 & 83.6 \\
July & 26.6 & 19.8 & 19.6 & 19.0 & 53.3 & 52.3 \\
August & 21.8 & 22.8 & 19.4 & 20.0 & 48.2 & 49.6 \\
September & 7.5 & 11.0 & 13.9 & 15.0 & 53.8 & 48.4 \\
\hline Total/Average & $\mathbf{2 1 6 . 4}$ & $\mathbf{1 3 3 . 6}$ & $\mathbf{1 5 . 4}$ & $\mathbf{1 6 . 2}$ & $\mathbf{5 7 . 6}$ & $\mathbf{6 0 . 4}$ \\
\hline
\end{tabular}

Experiments were conducted in randomized blocks design with three replications. Isera (early), C70165 (medium-early) and Teknosol (late) oil sunflower cultivars and six different nitrogen doses (0, $30,60,90,120$ and $\left.150 \mathrm{~kg} \mathrm{~N} \mathrm{ha}^{-1}\right)$ were used the material of the experiments. Sulphate $(21 \% \mathrm{~N})$ as nitrogenous fertilizer source and triple super phosphate $(45 \%)$ as phosphorus fertilizer source $(60 \mathrm{~kg}$ $\mathrm{ha}^{-1}$ ) were fully applied at sowing. Sowing was performed manually into the seedbeds in 2011 and 2012 respectively on 2nd and 11th of May with $70 \mathrm{~cm}$ row spacing and $25 \mathrm{~cm}$ on-row plant spacing (Kara, 1986). Hoeing was performed throughout the growing season for weed control and irrigations were performed especially during the flowering period. Plants were harvested when lower leaves, the sterile leaves around the head and fertile leaves within the head dried out and defoliated bract leaves turned into yellow or brown and all the seeds of head ripened on 18-28 September of 2011 and 10-18 September of 2012. 


\subsection{Analysis of Mineral Nutrient Contents}

Seeds were grinded in hand mill and $0.2 \mathrm{~g}$ sample was subjected to wet etching with nitric acid: hydrogen peroxide (2:3) in three steps (1st step: at $145{ }^{\circ} \mathrm{C} 75 \%$ microwave power for 5 minutes; 2 nd step: at $180{ }^{\circ} \mathrm{C} 90 \%$ microwave power for 10 minutes; $3 \mathrm{rd}$ step: at $100{ }^{\circ} \mathrm{C} 40 \%$ microwave power for 10 minutes) in a wet etching unit resistant to 40 bar pressure (speedwave MWS-2 Berghof products + Instruments Harresstr.1. 72800 Enien Gernmany) and then, P, K, Ca, Mg, Fe, Mn, Zn, Cd and Pb contents were determined by using an ICP OES spectrophotometer (Inductively Couple Plasma spectrophotometer) (Perkin-Elmer, Optima 2100 DV, ICP/OES, Shelton, CT 06484-4794, USA) (Mertens, 2005).

Statistical analysis: Statistical data analyses were performed by using SPSS software and differences among treatment means were compared by Duncan's multiple range tests at different significance levels.

\section{RESUlTS AND DisCUSSION}

With regard to effects of different nitrogen doses on $\mathrm{P}, \mathrm{K}, \mathrm{Ca}, \mathrm{Mg}, \mathrm{Fe}$ and $\mathrm{Zn}$ contents of common sunflower seeds, the effects of years, nitrogen doses, year $\mathrm{x}$ cultivar, year $\mathrm{x}$ nitrogen dose, cultivar $\mathrm{x}$ nitrogen dose and year $\mathrm{x}$ cultivar $\mathrm{x}$ nitrogen dose interactions were found to be significant $(\mathrm{p}<0.01)$. With regard to $\mathrm{Mn}$ content, entire parameters except for cultivar were found to be significant $(\mathrm{p}<0.01)$. On the other side, the effect of all parameters on $\mathrm{N}$ accumulation was found to be insignificant (Table 2).

Table 2. Effects of different nitrogen doses and cultivars on nutrient contents of the seeds of common sunflower cultivars grown in Erzurum in the years 2011 and 2012.

\begin{tabular}{|c|c|c|c|c|c|c|c|c|c|}
\hline \multicolumn{2}{|c|}{ Treatments } & $\begin{array}{c}\mathrm{N} \\
(\%) \\
\end{array}$ & $\begin{array}{c}\mathbf{P} \\
(\%)\end{array}$ & $\begin{array}{c}K \\
(\%)\end{array}$ & $\begin{array}{c}\mathrm{Ca} \\
(\%)\end{array}$ & $\begin{array}{l}\mathrm{Mg} \\
(\%)\end{array}$ & $\begin{array}{c}\text { Fe } \\
\left(\mathrm{mg} \mathrm{kg}^{-1}\right)\end{array}$ & $\begin{array}{c}\mathrm{Zn} \\
\left(\mathrm{mg} \mathrm{kg}^{1}\right)\end{array}$ & $\begin{array}{c}\text { Mn } \\
\left(\mathrm{mg} \mathrm{kg}^{1}\right)\end{array}$ \\
\hline \multirow{2}{*}{$\begin{array}{c}\text { Year } \\
(\mathbf{Y})\end{array}$} & 2011 & 4.06 & 0.74 & 6.60 & 0.70 & 0.85 & 125.8 & 41.9 & 30.2 \\
\hline & 2012 & 4.20 & 1.14 & 1.40 & 4.10 & 0.60 & 204.2 & 140.4 & 45.5 \\
\hline \multirow{3}{*}{$\begin{array}{c}\text { Cultivar } \\
\text { (C) }\end{array}$} & Isera & 4.16 & $0.94 \mathrm{~b}$ & $3.93 \mathrm{~b}$ & $2.65 \mathrm{a}$ & $0.75 \mathrm{a}$ & $162.6 \mathrm{~b}$ & $93.7 \mathrm{a}$ & 37.8 \\
\hline & C-70165 & 4.02 & $0.90 \mathrm{c}$ & $4.05 \mathrm{a}$ & $2.30 \mathrm{~b}$ & $0.70 \mathrm{c}$ & $151.7 \mathrm{c}$ & $90.0 \mathrm{~b}$ & 37.9 \\
\hline & Teknosol & 4.20 & $0.97 \mathrm{a}$ & $3.94 \mathrm{~b}$ & $2.35 \mathrm{~b}$ & $0.73 \mathrm{~b}$ & $180.6 \mathrm{a}$ & $89.8 \mathrm{~b}$ & 38.0 \\
\hline \multirow{6}{*}{$\begin{array}{c}\text { Nitrogen } \\
\text { Dose } \\
(\mathbf{N})\end{array}$} & $\mathbf{0}$ & 3.96 & $0.93 \mathrm{c}$ & $4.04 \mathrm{~b}$ & $2.52 \mathrm{~b}$ & $0.75 \mathrm{c}$ & $190.4 \mathrm{a}$ & $82.0 \mathrm{e}$ & $38.1 \mathrm{c}$ \\
\hline & 30 & 4.14 & $0.99 \mathrm{a}$ & $3.97 \mathrm{bc}$ & $2.19 \mathrm{~d}$ & $0.75 \mathrm{c}$ & $168.5 \mathrm{c}$ & $97.9 \mathrm{c}$ & $41.3 \mathrm{~b}$ \\
\hline & 60 & 4.27 & $0.98 \mathrm{ab}$ & $3.97 \mathrm{bc}$ & $2.86 \mathrm{a}$ & $0.77 \mathrm{a}$ & $159.8 \mathrm{~d}$ & $104.8 \mathrm{~b}$ & $35.6 \mathrm{~d}$ \\
\hline & 90 & 4.23 & $0.97 \mathrm{~b}$ & $3.62 \mathrm{~d}$ & $2.88 \mathrm{a}$ & $0.76 \mathrm{~b}$ & $158.6 \mathrm{~d}$ & $110.5 \mathrm{a}$ & $42.3 \mathrm{a}$ \\
\hline & 120 & 3.90 & $0.93 \mathrm{c}$ & $3.93 \mathrm{c}$ & $2.36 \mathrm{c}$ & $0.72 \mathrm{~d}$ & $172.3 \mathrm{~b}$ & $87.4 \mathrm{~d}$ & $37.5 \mathrm{c}$ \\
\hline & 150 & 4.27 & $0.81 \mathrm{~d}$ & $4.27 \mathrm{a}$ & $1.77 \mathrm{e}$ & $0.63 \mathrm{e}$ & $140.2 \mathrm{e}$ & $64.4 \mathrm{f}$ & $32.5 \mathrm{e}$ \\
\hline \multicolumn{10}{|c|}{ Analysis of variance } \\
\hline & $d f$ & $\begin{array}{c}N \\
(\%)\end{array}$ & $\begin{array}{l}\mathbf{P} \\
(\%)\end{array}$ & $\begin{array}{c}\mathbf{K} \\
(\%)\end{array}$ & $\begin{array}{l}\text { Ca } \\
(\%)\end{array}$ & $\begin{array}{l}\text { Mg } \\
(\%)\end{array}$ & $\begin{array}{c}\mathrm{Fe} \\
\left(\mathrm{mg} \mathrm{kg}^{-1}\right)\end{array}$ & $\begin{array}{c}\mathrm{Zn} \\
\left(\mathrm{mg} \mathrm{kg}^{1}\right)\end{array}$ & $\begin{array}{c}\mathrm{Mn} \\
\left(\mathrm{mg} \mathrm{kg}^{1}\right)\end{array}$ \\
\hline $\mathbf{Y}$ & 1 & ns & $* *$ & $* *$ & $* *$ & $* *$ & $* *$ & $* *$ & $* *$ \\
\hline $\mathbf{C}$ & 2 & ns & $* *$ & $* *$ & $* *$ & $* *$ & $* *$ & $* *$ & ns \\
\hline $\mathbf{N}$ & 5 & $\mathrm{~ns}$ & $* *$ & $* *$ & $* *$ & $* *$ & $* *$ & $* *$ & $* *$ \\
\hline $\mathbf{Y} \times \mathbf{C}$ & 2 & ns & $* *$ & $* *$ & $* *$ & $* *$ & $* *$ & $* *$ & $* *$ \\
\hline $\mathbf{Y} \times \mathbf{N}$ & 5 & ns & $* *$ & $* *$ & $* *$ & $* *$ & $* *$ & $* *$ & $* *$ \\
\hline $\mathbf{C} \times \mathbf{N}$ & 10 & ns & $* *$ & $* *$ & $* *$ & $* *$ & $* *$ & $* *$ & $* *$ \\
\hline $\mathbf{Y} \times \mathbf{C} \times \mathbf{N}$ & 10 & ns & $* *$ & $* *$ & $* *$ & $* *$ & $* *$ & $* *$ & $* *$ \\
\hline
\end{tabular}

*, ** Significant at 0.05 and 0.01 levels, respectively. ns, nonsignificant

N content: While nitrogen content was $4.06 \%$ in the year 2011, the value reached to $4.20 \%$ in 2012 . Seed nitrogen contents of the cultivars Isera, C-70165 and Teknosol were respectively observed as 4.16, 4.02 and $4.20 \%$. Based on nitrogen doses supplied to plants, seed nitrogen contents varied between 3.90-4.27\%. Highest nitrogen content in the seeds was obtained from 60 and $150 \mathrm{~kg}$ treatments and the lowest content was obtained from $120 \mathrm{~kg}$ nitrogen treatment. Steer et al. (1984) specified that $\mathrm{N}$ content of seeds is closely associated with nitrogen applied for the plant as well as their cultivar characteristic and environmental conditions. Correspondingly, they stated that it was expected to increase the $\mathrm{N}$ content of seeds depending on applied nitrogenous level and they found a similar variance. Solhi and Molahoseini (2013) and El-Kader et al. (2006) also reported that there was a positive impact of nitrogenous fertilizing on nitrogen accumulation in seeds. 


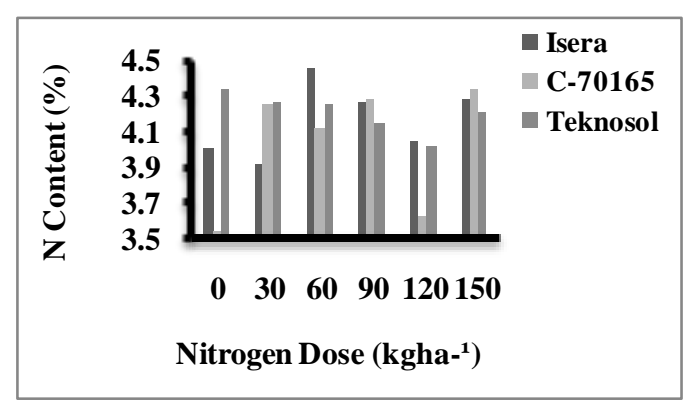

Figure 1. $N$ contents of sunflower seeds under different nitrogen doses

P content: Seed phosphorus content of the first year $(0.74 \%)$ was lower than the value observed in the second year $(1.14 \%)$ of the experiments. Considering the average of years and nitrogen doses, seed phosphorus content of the cultivar Teknosol $(0.97 \%)$ was higher than the phosphorus contents of the cultivars Isera $(0.94 \%)$ and C-70165 $(0.90 \%)$. Except for control treatment, seed phosphorus contents decreased with increasing nitrogen doses. Seed phosphorus contents of 0, 30, 60, 90, 120 and $150 \mathrm{~kg} \mathrm{ha}^{-1}$ nitrogen doses were respectively observed as $0.93,0.99,0.98,0.97,0.93$ and $0.81 \%$ (Figure 1). Singhal and Mudgal 1984 and El-Kader et al. 2006 also remarked that increasing nitrogen doses in the seeds reduced $\mathrm{P}$ content of the sunflower seed grains.

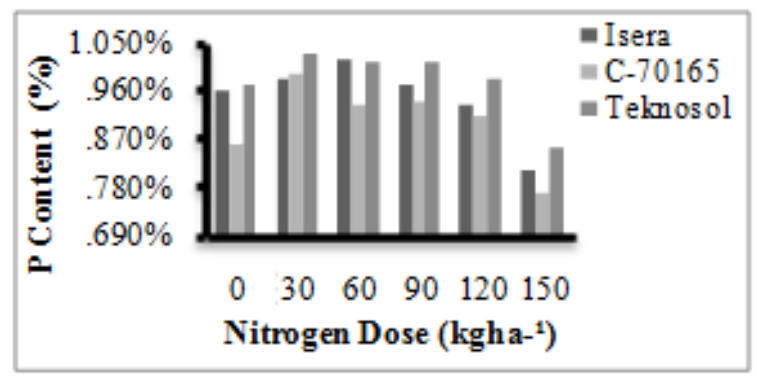

Figure 2. $P$ contents of sunflower seeds under different nitrogen doses

K content: Seed potassium content of the year 2011 (6.6\%) was 5.2\% higher than the seed phosphorus content of the year 2012 (1.4\%). Contrary to seed nitrogen and phosphorus contents, the highest seed potassium content was observed in the cultivar C-70165 (4.05\%). Under different nitrogen doses, the highest seed potassium accumulation (4.27\%) was observed in the highest nitrogen dose $\left(150 \mathrm{~kg} \mathrm{ha}^{-1}\right)$ and the lowest value was observed in $90 \mathrm{~kg} \mathrm{ha}^{-1}$ nitrogen dose. Increasing nitrogen and potassium contents and decreasing phosphorus contents with increasing nitrogenous fertilizer levels in sunflower seeds were also reported by the earlier studies (Kalra \& Tripathi, 1980; Mathers and Stewart, 1982; Bozkurt and Karacal, 2000).

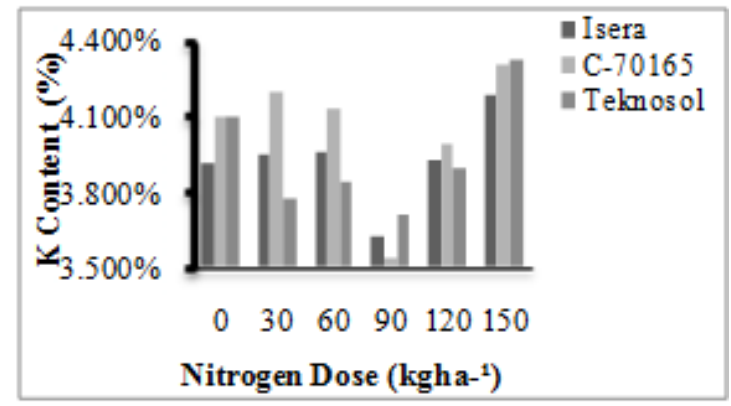

Figure 3. $K$ contents of sunflower seeds under different nitrogen doses

Ca content: Seed calcium content of the first year $(0.70 \%)$ was highly lower than the seed calcium content of the second year (4.10\%). Among the cultivars, calcium content of Isera (2.65\%) was higher than the calcium contents of the cultivars Teknosol (2.35\%) and C-70165 (2.30\%). The calcium contents of $0,30,60,90,120$ and $150 \mathrm{~kg}$ nitrogen treatments were respectively observed as 2.52 , $2.19,2.86,2.88,2.36$ and $1.77 \%$ with the highest $\mathrm{Ca}$ accumulation in 60 and $90 \mathrm{~kg} \mathrm{ha}^{-1}$ nitrogen treatments. Calcium contents slightly increased in medium level nitrogen treatments and decreased with increasing nitrogen doses. Similarly, Robinson (1973), Lasztity (1983) and Mathers and Stewart (1982) reported decreasing seed calcium contents with increasing nitrogenous fertilization levels. 


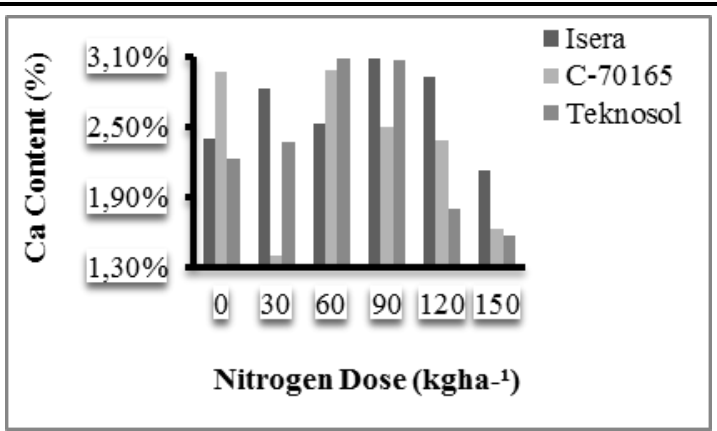

Figure 4. Ca contents of sunflower seeds under different nitrogen doses

Mg content: As the average of experimental factors, magnesium contents of the years 2011 and 2012 were respectively observed as 0.85 and $0.60 \%$. The average seed magnesium content of the cultivars was observed as $0.75 \%$ in Isera, $0.70 \%$ in C-70165 and $0.73 \%$ in Teknosol. While seed magnesium content was observed as $0.75 \%$ in control and $30 \mathrm{~kg} \mathrm{ha}^{-1}$ nitrogen dose, the value reached to the highest level of $0.77 \%$ in $60 \mathrm{~kg} \mathrm{ha}^{-1}$ nitrogen dose and decreasing magnesium contents were observed in 90,120 and $150 \mathrm{~kg} \mathrm{ha}^{-1}$ nitrogen treatments (respectively with magnesium contents of $0.76,0.72$ and $0.63 \%$ ). Some studies show that there were similarities with this study (Robinson, 1973; Lasztity, 1983; Bozkurt and Karacal, 2000).

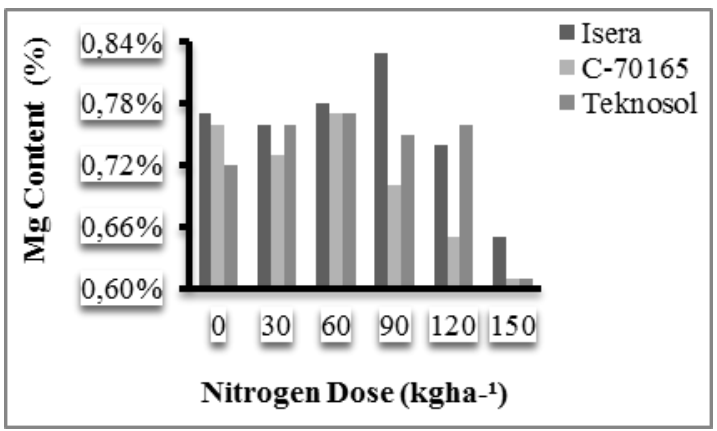

Figure 5. Mg contents of sunflower seeds under different nitrogen doses

Fe content: The seed iron content of the year $2012\left(204.2 \mathrm{mg} \mathrm{kg}^{-1}\right)$ was $78.4 \mathrm{mg} \mathrm{kg}^{-1}$ higher than the seed iron content of the year $2011\left(125.8 \mathrm{mg} \mathrm{kg}^{-1}\right)$. The iron content of sunflower cultivars was observed as $180.6 \mathrm{mg} \mathrm{kg}^{-1}$ in Teknosol, as $162.6 \mathrm{mg} \mathrm{kg}^{-1}$ in Isera and $151.7 \mathrm{mg} \mathrm{kg}^{-1}$ in C-70165 cultivar. The highest seed iron accumulation was observed in Teknosol cultivar. While the highest iron content was observed in control treatment $\left(190.4 \mathrm{mg} \mathrm{kg}^{-1}\right)$, decreasing iron contents were observed with increasing nitrogen doses. The seed iron contents of 30,60,90, 120 and $150 \mathrm{~kg}$ nitrogen treatments were respectively observed as 168.5, 159.8, 158.6, 172.3 and $140.2 \mathrm{mg} \mathrm{kg}^{-1}$ Bozkurt \& Karacal (2000) indicated decreasing Fe contents with increasing nitrogenous fertilization levels. On the other hand, some researchers indicated insignificant effects of nitrogenous fertilization on iron contents (Lasztity, 1983; Salama and Buzas, 1987).

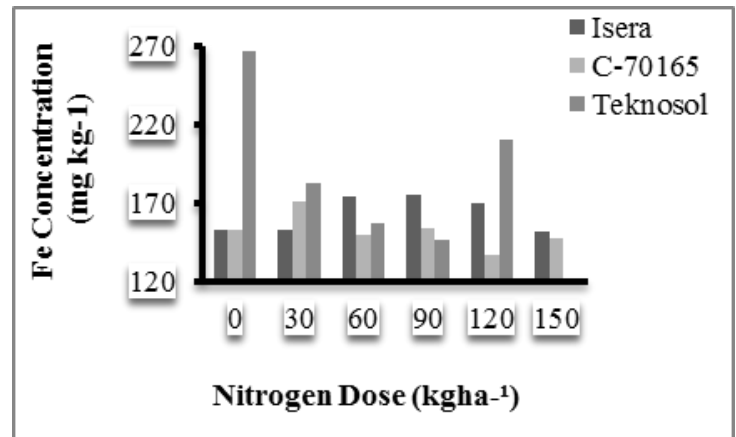

Figure 6. Fe contents of sunflower seeds under different nitrogen doses

Zn content: The zinc accumulation levels increased more in the second year and increased from 41.9 $\mathrm{mg} \mathrm{kg}^{-1}$ to $140.4 \mathrm{mg} \mathrm{kg}^{-1}$. The zinc accumulation levels of the cultivars Isera C-70165 and Teknosol were respectively observed as $93.7,90.0$ and $89.8 \mathrm{mg} \mathrm{kg}^{-1}$. The highest $\mathrm{Zn}$ content was observed in 
Isera and the lowest in Teknosol cultivar. The seed zinc contents of nitrogen treatments were lower than the zinc content of control treatment $\left(82.0 \mathrm{mg} \mathrm{kg}^{-1}\right)$. Zinc contents increased up to $90 \mathrm{~kg} \mathrm{ha}{ }^{-1}$ nitrogen treatment $\left(110.5 \mathrm{mg} \mathrm{kg}^{-1}\right)$ and decreased again in 120 and $150 \mathrm{~kg} \mathrm{ha}^{-1}$ treatments. In similar previous studies, seed zinc contents were reported as between 73.1-198 $\mathrm{mg} \mathrm{kg}^{-1}$ (Saric et al., 1997; Madejon et al., 2003). However, Bozkurt and Karacal (2000) and Hilton and Zubriski (1985) reported lower values for zinc contents of sunflower seeds.

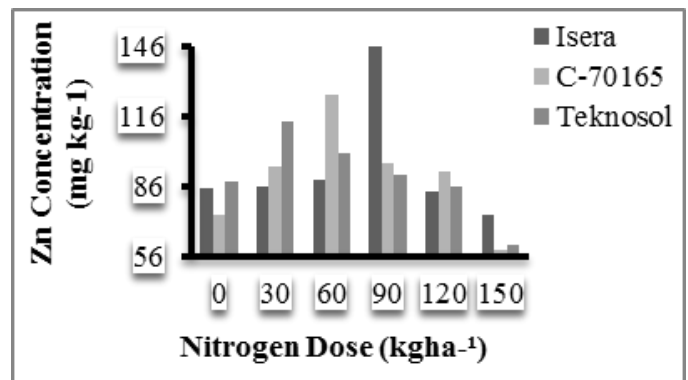

Figure 7. Zn contents of sunflower seeds under different nitrogen doses

Mn content: The seed manganese content of the first year $\left(30.2 \mathrm{mg} \mathrm{kg}^{-1}\right)$ was lower than the manganese content of the second year $\left(41.5 \mathrm{mg} \mathrm{kg}^{-1}\right)$. The seed manganese contents of the cultivars were close to each other with $38.0 \mathrm{mg} \mathrm{kg}^{-1}$ in Teknosol, $37.8 \mathrm{mg} \mathrm{kg}^{-1}$ in Isera and $37.9 \mathrm{mg} \mathrm{kg}^{-1}$ in C70165 cultivars. The seed manganese contents exhibited an irregular increase and decrease with nitrogen doses and varied between $32.5-42.3 \mathrm{mg} \mathrm{kg}^{-1}$. The highest manganese content was observed in $90 \mathrm{~kg} \mathrm{ha}^{-1}$ and the lowest value was observed in $150 \mathrm{~kg} \mathrm{ha}^{-1}$ nitrogen treatment. The seed manganese contents of $0,30,60$ and $120 \mathrm{~kg} \mathrm{ha}^{-1}$ doses were respectively observed as $38.1,41.3,35.6$ and $37.5 \mathrm{mg}$ $\mathrm{kg}^{-1}$. The seed manganese contents of the present study were parallel to the values reported by Solhi and Molahoseini (2013), (39.2 $\mathrm{mg} \mathrm{kg}^{-1}$ ) and Molahoseini et al. (2012), (39.27 $\mathrm{mg} \mathrm{kg}^{-1}$ ).

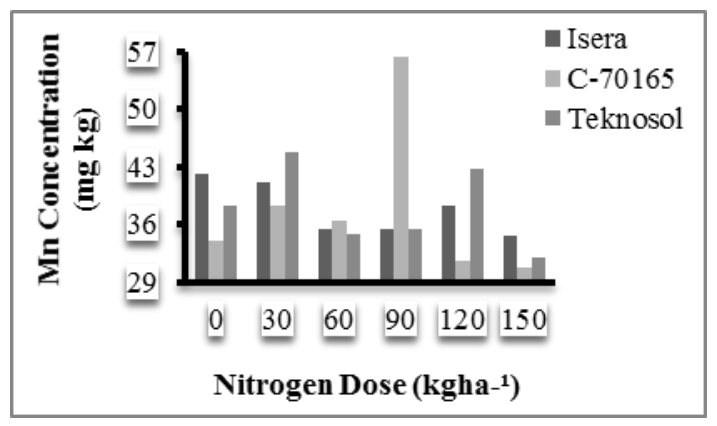

Figure 8. Mn contents of sunflower seeds under different nitrogen doses

\section{Conclusions}

Consequently, it is showed that the effect of nitrogenous fertilizing on nutrient content (except for $\mathrm{N}$ ) of sunflower cultivar's seeds is important. According to analysis results of seeds obtained from sunflower cultivars, the increase of nitrogenous doses cause to increase $\mathrm{N}$ and $\mathrm{K}$ content of seeds, and significantly decrease $\mathrm{P}, \mathrm{Ca}, \mathrm{Mg}, \mathrm{Fe}$ and $\mathrm{Mn}$ content of the seeds. $\mathrm{Cu}$ and $\mathrm{B}$ levels were not consistent. In recognition of $\mathrm{Zn}$ content, it was increased to the certain level but later it was decreased. With regard to cultivars, Isera and Teknosol have highest nutrient in terms of seed grains.

\section{REFERENCES}

[1] Brady, N.C and Weil, R.R. The nature and properties of soils. Pearson Prentice Hal Include New Jersey USA (2008).

[2] Bozkurt, M.A and Karacal, I. Effects of different nitrogenous fertilizer doses and forms on nutrient content in sunflower. Ankara University Faculty of Agriculture. Journal of Agricultural Sciences. 6:99-105 (2000).

[3] Burt, C., Connor, K.O and Ruehr, T. Fertigation. The Irrigation Training and Research Center. California Polytechnic State University, San Luis Obispo (1998).

[4] Demirci, M and Alpaslan, M. Condition of the vegetable oil industry in Turkey. Agro-Technical Journal of Agricultural. 6:34-35 (1991). 
[5] El-Kader, A.A.A., Mohamedin, A.A.M and Ahmed, M.K.A. Growth and yield of sunflower as affected by different salt affected soils. International Journal of Agriculture Biology. 8:583-587 (2006).

[6] Gecit, H.H., Ciftci, C.Y., Emeklier, H.Y., Ikincikarakaya, S., Adak, S., Kolsarici, O., Ekiz, H., Altunok, S., Sancak, C., Sevimay, C.S and Kendir H. Field Crops. Ankara University Faculty of Agriculture Publications: 1569, Textbook: 521, Ankara (2009).

[7] Grant, C. Enhancing nitrogen use efficiency in dry land cropping systems on the northern Great Plains. 18 th World Congress of Soil Science. July 9-15, 2006, Philadelphia, USA (2006).

[8] Hilton, B.R and Zubriski, J.C. Effects of sulfur, zinc, iron, copper, manganese and boron applications on sunflower yield and plant nutrient concentration. Communication in Soil Science Plant Anal. 16: 411-425 (1985).

[9] Kacar B. Soil Analyses (II. press). Nobel Press Number: 1387, Ankara (2009).

[10] Kaleem, S., Hassan, F.U., Farooq, M., Rasheed, M and Munir A. Physio-morphic traits as influenced by seasonal variation in sunflower; A review. International Journal of Agriculture Biology. 12:468-473 (2010).

[11] Kalra, G.S and Tripathi, P.N. Nutrient uptake and quality of sunflower as influenced by NPK fertilization. Indian Journal Agron. 25:710-716 (1980).

[12] Kara, K. A Research on yield and yield components with phenological, morphological characteristics of some oil sunflower varieties in Erzurum ecological condition. Doga Turkish Journal of Agriculture and Forestry 1:366-37 (1986).

[13] Kastori, R.R., Maksimović, I.V., Putnik-Delić, M.I., Zeremski-Škorić, T.M. Rare earth elements: yttrium and higher plants. Matica Srpska Proceedings for Natural Sciences.118:87-98 (2010).

[14] Konya Y. Fertilization in sunflower. Yield Bulletin with Gubretas, 12, Ankara (2008).

[15] Lasztity, B. Development and nutrient turnover during the vegetation period as affected by fertilization in sunflower, I. Dry matter accumulation and nutrient content. Novenytermeles. 32:137-148 (1983).

[16] Madejon, P., Murillo J.M., Maranon, T., Cabrera, F. and Soriano, M.A. Trace element and nutrient accumulation in sunflower plants two years after the aznalcollar mine spill. The Science of The Total Environment. 307:239-257 (2003).

[17] Mathers, A.C., Stewart, B.A. Sunflower nutrient uptake growth and yields as effected by nitrogen or manure, and plant population. Agronomy Journal. 74:911-915 (1982).

[18] Mertens, D. AOAC Official Method 975.03. Metal in Plants and Pet Foods. Official Methods of Analysis. 18 th Ed. Horwitz, W., and G.W. Latimer, (Eds). Chapter 3, pp 3-4, AOACInternational Suite 500, 481. N F Avenue, Gaitherburg, Maryland 20877 2417, USA (2005).

[19] Miller, J.F., Zimmerman, D.C., Vick, B.A. Genetic control of high oleic acid in sunflower. Oil Crops Science. 27:923-926 (1987).

[20] Molahoseini, H., Feizi, M. and Seilsepour, M. The concentration of some essential elements and cadmium in sunflower, turnip and forage corn under wastewater irrigation. The 1th International and The 4th National Congress on Recycling of Organic Waste in Agriculture. April 26-27, 2012, Iran (2012).

[21] Pajević, S., Kevrešan, Ž., Vučković, M., Radulović, S., Frontasayeva, M., Pavlov, S. and Galinskaya, T. Aquatic macrophytes as biological resources for monitoring the impacts of heavy metals on the aquatic environment. $35^{\text {th }}$ IAD Conference, Novi Sad, Serbia and Montenegro, Limnological.0:323-330 (2004).

[22] Robinson, R. G. The Sunflower crop in minnesota. Minnesota Agriculture Extension Bull. 299:1-28 (1973).

[23] Salama, A.M. and Buzas, I. Effect of growth regulators and NPK fertilizers on the trace elements contents of sunflower in calcareous soils. Acta Agronomica Hungarica. 36:37-42 (1987).

[24] Saric, M., Dragana Vasic, L.J.,Vasiljevic, D., Skoric, S.M. and Slobodanka, P. Concentration of mineral element in callus tissue culture of some sunflower inbred lines. Romanian Agricultural Research.0:7-8 (1997).

[25] Singhal, K.K. and Mudgal, V.D. Macro and micro-elements of feed, fodder and agro industrial by products. Indian Journal Animal Science. 54:685-691 (1984). 
Volkan GUL et al.

[26] Solhi, M. and Molahoseini, H. Nutrient heavy metal concentration and distribution in corn, sunflower and turnip cultivated in a soil under wastewater. International Journal of Agronomy and Plant Production. 4:2147-2151 (2013).

[27] Steer, B.T. and Hocking, P.J. Nitrogen nutrition of sunflower (Helianthus annuus L.) acquisition and partitioning of dry matter and nitrogen by vegetative organs and their relationship on seed yield. Field Crops Research. 9:237-51 (1984).

[28] Taylor, B.A., Hoch, H. and Weissman, M. The analysis and treatment of vocal stereotypy in a child with autism. Behavior Interventions. 20:239-250 (2005). 